\title{
The Religious Orientation Scale Revised among Spanish Catholic People: Structural Validity and Internal Consistency of a 21- item Model ${ }^{*}$
}

Escala de Orientación Religiosa revisada en católicos españoles: validez estructural y consistencia interna de un modelo de 21 ítems

Received: 20 August 2018 | Accepted: 18 July 2019

\author{
JoAquín García-Alandete ${ }^{\mathrm{a}}$ \\ Universidad Católica de Valencia San Vicente Mártir, \\ Spain \\ ORCID: http://orcid.org/0000-0003-0769-4060 \\ César Rubio-Belmonte \\ Universidad Católica de Valencia San Vicente Mártir, \\ Spain \\ ORCID: https://orcid.org/0000-0003-0689-4984 \\ Beatriz Soucase-Lozano \\ Universidad Católica de Valencia San Vicente \\ Mártir, Spain \\ ORCID: https://orcid.org/0000-0002-3385-960X
}

a Correspondence author. Email: ximo.garcia@ucv.es

How to cite: García-Alandete, J., Rubio-Belmonte, C., \& Soucase-Lozano, B. (2019). The religious orientation scale revised among Spanish catholic people: Structural validity and inter-nal consistency of a 21-item model. Universitas Psychologica, 18(3), 1-12. https://doi.org/10.11144/ Javeriana.upsy18-3.rosr

\begin{abstract}
The personal religious orientation understood as the motivation behind religious behaviors must be considered as the process that manages and organizes the behavior of those who are religious. Thus, identifying the dimensionality of religiosity is important (Francis, 2007; Kirkpatrick \& Hood, 1990). This paper analyzed the structural validity and internal consistency of the 31-item Batson and Ventis Religious Orientation Scale. Participants were 529 Spanish Catholic undergraduates aged between 18 and 55 years, $M=21.55, S D=4.39$. A Principal Component Analysis with Equamax rotation method was performed on the ROS-31 with the randomized $50 \%$ of the sample, obtaining a 21 -item three-component model (intrinsic, extrinsic, and quest religious orientations). Then, a CFA carried out with the other $50 \%$ of the sample showed an adequate fit of the obtained model, $\mathrm{SB}^{2}{ }_{(186)}=352.45, p<0.01, \mathrm{CFI}=0.93$, IFI $=0.93$, RMSEA $=0.059(\mathrm{CI} 90 \%[0.049,0.067])$. The intrinsic scale showed an excellent internal consistency, the quest scale showed good internal consistency, and the extrinsic scale showed an acceptable internal consistency. Future lines of research are suggested in order to clarify the relationship between the religious orientation scales and some psychosocial variables.

Keywords

religious orientation scale; construct validity; exploratory factor analysis; confirmatory factor analysis; internal consistency; catholic people.
\end{abstract}




\section{RESUMEN}

La orientación religiosa personal, entendida como la motivación subyacente a las conductas religiosas, debe ser considerada como el proceso que dirige y organiza la conducta de las personas religiosas. Identificar la dimensionalidad de la religiosidad parece, pues, ser importante. Este trabajo analiza la validez estructural y la consistencia interna de la Escala de Orientación Religiosa de Batson y Ventis de 31 ítems (ROS-31). Participaron 529 universitarios españoles con edades entre los 18 y los 55 años, $\mathrm{M}=21.55, \mathrm{SD}=4.39$. Se llevó a cabo un Análisis de Componentes Principales con rotación Equamax de la ROS-31 con el 50\% aleatorio de la muestra, obteniendo un modelo de 3 componentes y 21 ítems (orientación religiosa intrínseca, extrínseca y de búsqueda). Un Análisis Factorial Confirmatorio con el otro 50\% aleatorio de la muestra mostró un ajuste adecuado del modelo, $\mathrm{SB} \chi^{2}$ (186) $=352.45, p<0.01, \mathrm{CFI}=0.93, \mathrm{IFI}=0.93, \mathrm{RMSEA}=$ 0.059 (IC 90\% [0.049, 0.067]). La escala de religiosidad intrínseca mostró una consistencia interna excelente, la de búsqueda una consistencia interna buena y la extrínseca una consistencia interna aceptable. Se sugieren líneas futuras de investigación en orden a clarificar la relación entre las escalas de orientación religiosa y algunas variables psicosociales.

Palabras clave

escala de orientación religiosa; validez de constructo; análisis factorial exploratorio; análisis factorial confirmatorio; consistencia interna; católicos.

Religiosity has frequently been assessed in terms of its religious self-definition the frequency of cult attendance and prayer behavior, among other variables. However, religious differences between people might not only be a question of degree, as they can also be qualitative. Therefore, the religious orientation understood as the motivation behind religious behaviors must be considered as the process that manages and organizes the behavior of those who are religious (Allport \& Ross, 1967). Thus, identifying the dimensionality of religiosity is important (Francis, 2007; Kirkpatrick \& Hood, 1990).

\section{Intrinsic, extrinsic, and quest religious orientations}

Allport (1950) distinguished the difference between mature and immature religiosity. The former is related to the integration and organization of the personality, a consistent morality, and an intricate, flexible cognitive style, whereas the latter is related to selfgratification, which does not contribute to the integration of the personality or selfreflection. These orientations were later called intrinsic (IRO) and extrinsic (ERO), respectively (Allport, 1950). IRO implies the experience of religion as an end in itself and a fundamental motivation. It is an absolute criterion in decision making that integrates one's entire existence and provide meaning in life. Religion implies the internalization of a coherent system of beliefs and the experience of religion as valuable and meaningful; religion ultimately influences one's life; the rest of the needs are considered less important and are harmonized with religious beliefs; the individual lives the religion. ERO is a practical orientation: religion is a means for achieving specific purposes, such as security, social status, or support for one's lifestyle. Religion is an instrument, and the beliefs system is maintained to satisfy the more primary needs; extrinsic religiosity is egocentric (Allport \& Ross, 1967). As Allport and Ross stated, "the extrinsically motivated individual uses his religion, whereas the intrinsically motivated lives his" (1967, p. 434). The IRO-ERO conceptual distinction has been revised, confirmed, and extended for decades (e.g., Allen \& Spilka, 1967; Batson \& Ventis, 1982; Batson, Schoenrade, \& Ventis, 1993; Hunt \& King, 1971; Maltby et al., 2010).

To assess these religious orientations, Allport and Ross (1967) developed the Religious Orientation Scale (ROS), a 20-item scale (11 extrinsic items, 9 intrinsic items) that has been revised, criticized, and modified in later studies (e.g. Brewczynski \& MacDonald, 2006; Darvyri et al., 2014; Khodadady \& Bagheri, 2012; Maltby, 2002; Neyrinck, Lens, Vansteenkiste, \& Soenens, 2010; Simkin \& Etchezahar, 2013). Allport and Ross (1967) obtained a Cronbach's alpha of 0.73 for the intrinsic scale and 0.70 for the extrinsic.

Batson (1976) criticized the fact that Allport substantially modified the meaning of the religious orientations by changing their names, and he suggested three independent religious orientations: Means, end, and quest (Batson \& 
Schoenrade, 1991a, 1991b; Batson \& Ventis, 1982, 1985). Means and end orientations are conceptually equivalent to Allport's (1950) ERO and IRO. Quest religious orientation $(\mathrm{QRO})$ is a flexible, open-ended religiosity in a responsive dialogue about existential questions raised by life's contradictions and tragedies. As Batson et al. (1993) stated, the QRO "involves honestly facing existential questions in all their complexity, while at the same time resisting clear-cut, pat answers" (p. 166). Batson (1976) considered that the QRO is mature, while the IRO (the most positive, accurate, and genuine for Allport) is dogmatic, uncritical, and rigid. Recent studies have revised the end, means, and quest dimensions of religiosity (e.g. Voci, Bosetti, \& Veneziani, 2017). Batson and Ventis (1982) obtained a Cronbach's alpha of 0.83 for the intrinsic scale, 0.78 for the quest, and 0.72 for the extrinsic.

Batson and Ventis (1982) developed the Quest Scale (also called the Interactional Scale), which included 6 items that assess three dimensions as distinct constructs: the individual's readiness to face existential questions without reducing their complexity, self-criticism and perception of religious doubts as positive, and openness to change (Cfr. Batson, Schoenrade, \& Ventis, 1993; Flere, Edwards, \& Klanjsek, 2008; Watson, Morris, \& Hood, 1989). Afterward, Donahue (1985) suggested that quest might measure agnosticism or religious conflict rather than religious orientation, and he proposed a 12 -item quest scale (Cfr. Batson \& Schoenrade, 1991a, 1991b).

The nature of the QRO and its relationship with both the intrinsic and extrinsic scales have been revised and criticized for decades (e.g., Flere et al., 2008; Miner, 2008). Nonetheless, the three religious orientations are accepted and frequently used constructs in the empirical research on religiosity (e.g., Brown \& Westman, 2011; García-Alandete, Rosa, Sellés, \& Soucase, 2013; Jaume, Simkin, \& Etchezahar, 2013).
Structural validity and internal consistency of the ROS

Only a small number of studies have analyzed the factor structure of the ROS. Maltby (1999a), with a sample of 3090 adults and schoolchildren (1408 males, 1984 females) from the USA (N $=513)$, England $(N=1421)$, Northern Ireland $(N=839)$ and the Republic of Ireland $(N=$ 468), obtained a 12 -item version of the ROS using PCA with Oblimin rotation. In the socalled 'Age-Universal' I-E Scale, in which he left out several items related to personal and communitarian praying and one item related to church attendance, which might be understood as both intrinsic (personal commitment) and extrinsic (social expression). On the other hand, this author criticized the fact that the item It doesn't much matter what I believe so long as I am good was not typical of the ERO, and that it might not even be a strictly religious item.

Ramírez (2006), in a sample of Spanish undergraduates, obtained a 27 -item version of the ROS using a PCA with Quartimax rotation. The final solution was a 3-component scale: intrinsic (items 2, 7, 9, 12, 15, 19, 21, and 27; $\alpha$ $=0.89$ ), extrinsic (items $1,13,14,18,22,23,25$, 28 , and $30 ; \alpha=0.72$ ), and quest (items $3,5,6,8$, $10,11,20,24,26$, and $31 ; \alpha=0.73$ ).

Núñez-Alarcón, Moreno-Jiménez, MoralToranzo, and Sánchez (2011) carried out a PCA with Quartimax rotation and a CFA of a 25-item version of the Ramírez (2006) Spanish adaptation in two samples: 211 Christian undergraduates and 121 Muslim undergraduates. For the Christian sample, the ROS was composed of 3 scales: intrinsic (items 2, 7, 11, 14, and 16; $\alpha$ $=0.85$ ), extrinsic (items $9,10,18,23$, and 24; $\alpha$ $=0.73$ ), and quest (items 5, 6, 15, and 19; $\alpha=$ 0.75), $\chi^{2}(73)=152.01, \mathrm{p}=0.000, \mathrm{CFI}=0.90$, $\mathrm{IFI}=0.90$, RMSEA $=0.074$. For the Muslim sample, the ROS was also composed of 3 scales: intrinsic (items 2,7 , and 22; $\alpha=0.81$ ), extrinsic (items 1, 9, 10, and 13; $\alpha=0.74$ ), and quest (items 3, 5, 8, 15, 19, and 25; $\alpha=0.81$ ), with an acceptable fit: $\chi^{2}(58)=93.85, p=0.002, \mathrm{CFI}=$ 0.93, IFI $=0.93$, RMSEA $=0.082$. 
Ramírez (2006) and Núñez-Alarcón et al. (2011) performed a CFA with the same sample with which carried out an exploratory procedure. As it is known, it is not a good methodological practice (e.g., Browne \& Cudeck, 1993).

Khodadady and Golparvar (2011) explored the factorial structure of the ROS using a version that included the 20-item scale developed by Allport and Ross (1967), and another item added by Feagin (1964), in 329 Iranian undergraduates. These authors employed Maximum Likelihood, Principal Axis Factoring, and PCA, and they extracted four factors, challenging the Allport and Ross (1967) distinction of two factors.

\section{The current study}

The aim of the present study was twofold: First, to analyze the factorial structure of the ROS using a Spanish translation (Ramírez, 2006); second, to estimate the internal consistency of the ROS among Spanish Catholic people.

\section{Method}

\section{Participants}

Participants were 529 Spanish undergraduates (367 women, 69.40\%, and 162 men, 30.60\%) aged between 18 and 55 years, $M=21.55$, $S D=4.39$, recruited from different faculties in a private Spanish university: Physical Therapy $(n=125,23.63 \%)$, Social Education $(n=$ 101, 19.10\%), Occupational Therapy $(\mathrm{n}=85$, $16.07 \%)$, Psychology $(n=80,15.12 \%)$, Law Sciences $(n=49,9.26 \%)$, Speech Therapy $(n=46,8.70 \%)$, Podiatry $(n=26,4.91 \%)$ and Educational Sciences $(n=17,3.21 \%)$. Most of the participants were unmarried ( $n$ $=506,95.65 \%$ ), followed by those who was married or lived with a common-law partner $(n=22,4.16 \%)$, and by divorced $(n=1$, 0.19\%). All participants reported to be Catholics and believers. Participation was voluntary and participants did not receive any compensation for their contribution.

\section{Instrument}

Religious Orientation Scale (ROS) (Batson \& Ventis, 1982). We used the Ramírez (2006) Spanish translation, a 31-item scale (ROS-31 henceforth): 8 for the intrinsic scale, 11 for the extrinsic, and 12 for the questionnaire, which is responded to on a Likert-type scale ( $1=$ Strongly disagree; $9=$ Strongly agree). Ramírez (2006) obtained Cronbach's alphas of 0.89, 0.73, and 0.72 , respectively. In the current study, the internal consistency was very good for the intrinsic scale, $\alpha=0.94$, good for the quest, $\alpha=$ 0.83 , and acceptable for the extrinsic, $\alpha=0.77$.

Procedure

Participants were recruited in a Spanish university, and they were asked for their informed consent and filled out a protocol that included the Spanish adaptation of the ROS-31 (Ramírez, 2006), under the supervision of the authors. Anonymity was guaranteed, doubts were resolved, and the need to give honest answers was highlighted, in order to maximize the validity of the information. The average time to fill out the protocol was 30 minutes.

\section{Data analyses}

A Confirmatory Factor Analysis (CFA) of the ROS-31 was performed. Because the model showed an inadequate fit, a Principal Component Analysis (PCA) extraction method and Equamax rotation method were carried out in the randomly selected $50 \%$ of the sample (Browne \& Cudeck, 1993). In addition to both the Kaiser-MayerOlkin measure and Bartlett's sphericity test, the following criteria were taken into account: (1) the component loading of the items should be $\geq$ 0.40 ; (2) the items which loaded $\geq 0.40$ in two or more components would be removed; (3) the component in which at least 3 items did not load $\geq 0.40$ would be dismissed.

Then, a CFA of the final solution was carried out in the other $50 \%$ of the sample. Because 
it was not possible to assume multivariate normality, robust estimation was used (Satorra \& Bentler, 2001). Fit indices included the Comparative Fit Index (CFI) and Tucker-Lewis Index (TLI) (a score between 0.90 and 0.95 indicates reasonable model fit), and Root Mean Square Error of Approximation (RMSEA) (a score lower than 0.050 is optimal, a score between 0.050 and 0.080 suggests an acceptable fit, a score between 0.080 and 0.10 suggests a mediocre fit, and a score higher than 0.10 indicates an unacceptable fit) (e.g., Hair, Anderson, Tatham, \& Black, 2006).

The reliability of the obtained model for the ROS was analyzed by estimating the Cronbach's alpha. A reliability index $\geq 0.70,0.80$, or 0.90 can be interpreted as acceptable, good, or excellent, respectively. Also, following the suggestions of experts (e.g., Brown, 2015), the Composite Reliability (CR) was calculated for each scale of the obtained model for the ROS.

For the PCA, descriptive statistics, correlations, and estimation of the internal consistency, the SPSS Statistics 22.0 program for Windows (IBM, 2013) was used. Interpretation of effect sizes for $r$ was based on Cohen (1988). For the CFA, the EQS 6.1 for Windows (Bentler, 2006) was used.

\section{Results}

Descriptive statistics and Confirmatory Factor Analysis of the ROS-31

Descriptive statistics of the ROS-31 items are shown in Table 1. A CFA showed an inadequate fit of this model: $\mathrm{SB}^{2}{ }_{(434)}=2221.85, p<0.01$, $\mathrm{CFI}=0.75$, TLI $=0.75, \mathrm{RMSEA}=0.088(90 \%$ CI $[0.085,0.092])$.
Table 1

Means and standard deviations of the ROS-31

items

\begin{tabular}{|c|c|c|c|}
\hline Item & Statement & $M$ & $S D$ \\
\hline $1(\mathrm{E})$ & The primary purpose of prayer is to gain relief and protection. & 4.79 & 2.57 \\
\hline 2(I) & It is important for me to spend periods in private religious thought and medi & 3.60 & 2.48 \\
\hline $3(\mathrm{Q})$ & As I grow and change, I expect my religion also to grow and change. & 3.93 & 2.72 \\
\hline $4(\mathrm{E})$ & Although I believe in my religion, I feel there are many more important things in my life. & 5.41 & 2.38 \\
\hline $5(\mathrm{Q})$ & I am constantly questioning my religious beliefs. & 3.04 & 2.34 \\
\hline $6(\mathrm{Q})$ & It might be said that I value my religious doubts and uncertainties. & 3.94 & 2.56 \\
\hline 7(I) & If not prevented by unavoidable circumstances, I attend church. & 2.37 & 2.30 \\
\hline $8(\mathrm{Q})$ & $\begin{array}{l}\text { I was not very interested in religion until I began to ask questions about the meaning and } \\
\text { purpose of my life. }\end{array}$ & 2.35 & 2.02 \\
\hline 9(I) & I try hard to carry my religion over into all my other dealings in life. & 2.89 & 2.54 \\
\hline 10(E) & It doesn't matter so much what I believe so lon & 5.57 & 2.79 \\
\hline $11(\mathrm{Q})$ & For me, doubting is an important part of what it means to be religious. & 3.67 & 2.47 \\
\hline 12(I) & $\begin{array}{l}\text { The prayers I say when I am alone, carry as much meaning and personal emotion as those } \\
\text { said by me during services. }\end{array}$ & 3.19 & 2.68 \\
\hline 13(E) & $\begin{array}{l}\text { The church is most important as a place to formulate good social relationships. } \\
\text { The }\end{array}$ & 3.10 & 2.40 \\
\hline 14(E) & What religion offers me most is comfort when sorrows and misfortune strike. & 3.70 & 2.63 \\
\hline $15(\mathrm{I})$ & Quite & 3.33 & 2.60 \\
\hline $16(Q)$ & I do not expect my religious convi & 5.63 & 2.44 \\
\hline $17(\mathrm{Q})$ & I find religious doubts upsetting. & 3.22 & 1.99 \\
\hline 18(E) & I pre & 2.64 & 2.27 \\
\hline 19(1) & I read literature about my faith (or church). & 2.28 & 2.02 \\
\hline $20(Q)$ & $\begin{array}{l}\text { estions out of a growing awareness of the tensions } \\
\text { orld. }\end{array}$ & 3.57 & 2.66 \\
\hline 21(1) & My religious beliefs are what really lie behind my whole approach to life. & 3.15 & 2.64 \\
\hline 22(E) & $\begin{array}{l}\text { a religious person, I refuse to let religious considerations influence my } \\
\text { rs. }\end{array}$ & 3.65 & 2.70 \\
\hline 23(E) & $\begin{array}{l}\text { A primary reason for my interest in religion is that my church is a congenial social } \\
\text { activity. }\end{array}$ & 2.53 & 2.00 \\
\hline $24(Q)$ & My life experiences have led me to rethink my religious con & 3.84 & 2.73 \\
\hline $25(\mathrm{E})$ & compromise my religious beliefs in order to protect & 2.58 & 2.02 \\
\hline $26(\mathrm{Q})$ & which my views are still changing. & 3.82 & 2.62 \\
\hline $27(\mathrm{I})$ & $\begin{array}{l}\text { pecially important to me because it answers many questions about the } \\
\text { e. }\end{array}$ & 3.40 & 2.64 \\
\hline 28(E) & $\begin{array}{l}\text { One reason for my being a church member is that such membership helps to establish a } \\
\text { person in the community. }\end{array}$ & 2.14 & 1.79 \\
\hline $29(Q)$ & be the truth about religion. & 4.66 & 2.42 \\
\hline $30(\mathrm{E}$ & The pt & & 24 \\
\hline $31(\mathrm{C}$ & & 4.0 & \\
\hline
\end{tabular}

Principal Component Analysis of the ROS-31

A PCA extraction method with Equamax rotation method was performed on the ROS-31 (Table 2) with the randomized $50 \%$ of the sample $(N=264 ; 194$ women, $73.5 \%$, and 70 men; $\left.M_{\text {age }}=22.34, S D=5.78\right)$. The final solution showed a three-component model: Component 1 was composed by 8 items $(2,7,8,9,12,19,21$, and $27 ; 25.86 \%$ of the variance); component 2 comprised 7 items $(5,6,11,20,24,26$, and 31 ; $16.83 \%$ of the variance); component 3 included 6 items $(14,22,23,25,28$, and 30; 13.42\% of the variance). These components were called Intrinsic Religious Orientation (IRO), Quest Religious Orientation (QRO), and Extrinsic Religious Orientation (ERO), respectively. These components showed positive correlationships with an intermediate effect size (Cohen, 1988): $r_{\text {(IRO-ERO) }}=0.46, r_{(\mathrm{IRO}-\mathrm{QRO})}=0.39$, and $r$ $(\mathrm{ERO}-\mathrm{QRO})=0.48$. The obtained scale was called Religious Orientation Scale-21 Items (ROS-21). 
Table 2

Principal Component Analysis of the ROS-31

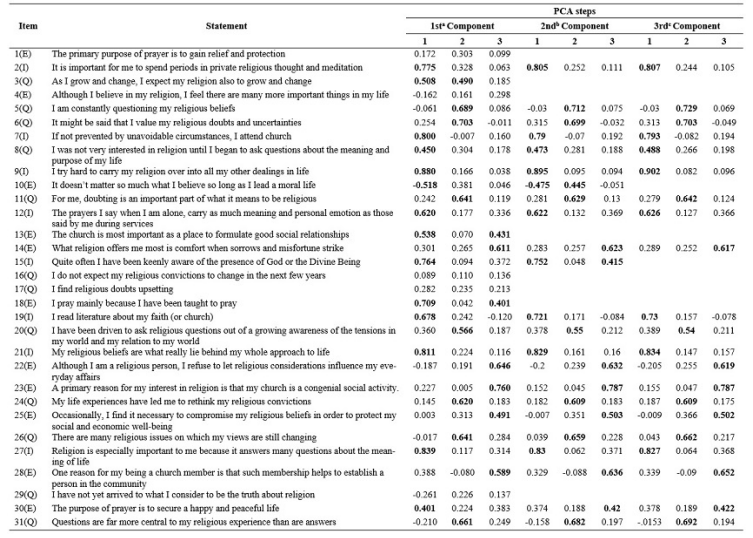

Note.Extraction method: Principal Component

Analysis. Rotation method: Equamax with

Kaiser normalization. EV = Explained

variance. In parenthesis, the religious

orientation: $(\mathrm{E})=$ Extrinsic; $(\mathrm{I})=$ Intrinsic;

$(\mathrm{Q})=$ Quest. ${ }^{\mathrm{a}}$ Rotation converged in

11 iterations. ${ }^{\mathrm{b}}$ Rotation converged in 7

iterations. ${ }^{\mathrm{c}}$ Rotation converged in $7 \mathrm{i}$ iterations.

\section{Confirmatory Factor Analysis of the ROS-21}

A CFA carried out with the other $50 \%$ of the sample $(N=265 ; 173$ women, $65.3 \%$, and 92 men; $\left.M_{\text {age }}=20.76, S D=2.01\right)$ showed an adequate fit of the obtained model, $\mathrm{SB} \chi^{2}$ $(186)=352.45, p<0.01, \mathrm{CFI}=0.93$, IFI $=$ 0.93, RMSEA $=0.059$ (CI 90\% [0.049, 0.067]). All the parameters of the standardized equation showed acceptable values, $p<0.05$ (Figure 1 ).
Figure 1

Standardized solution for the 21-item model for the ROS obtained in the present study

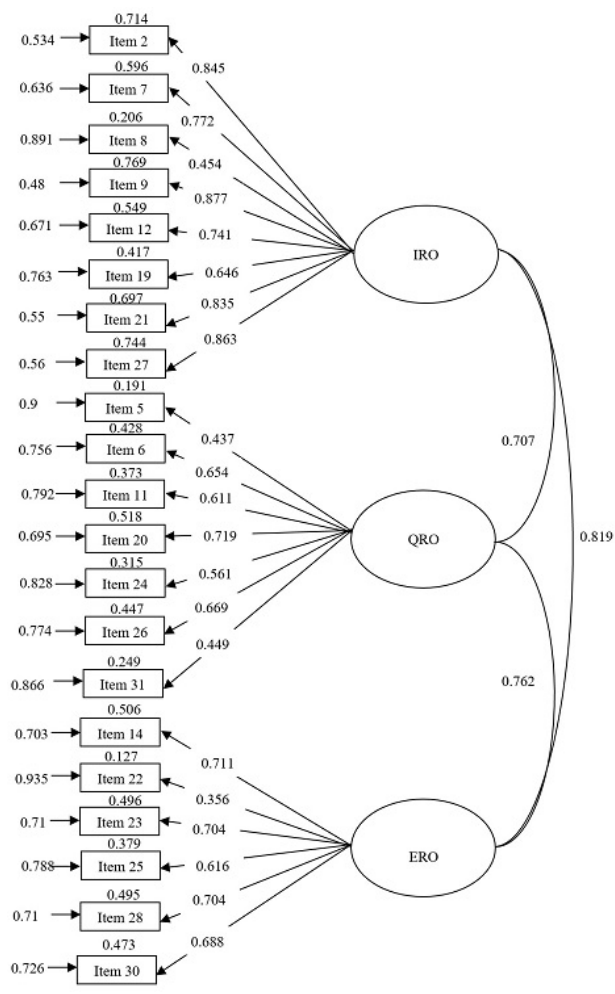

Note. Values at the top of each rectangle are $\mathrm{R}^{2}$; values at the left of each rectangle are errors

\section{Reliability of the ROS-21}

The IRO scale showed an excellent Cronbach's alpha, $\alpha=0.92$, the $\mathrm{QRO}$ showed a good Cronbach's alpha, $\alpha=0.82$, and the ERO showed an acceptable Cronbach's alpha, $\alpha=0.72$. The right internal consistency of these scales was confirmed with the CR, which was 0.88 for the IRO scale, 0.76 for the QRO scale, and 0.76 for the ERO scale. Given that the minimum value considering suitable for $\mathrm{CR}$ is 0.70 (Hair, Hult, Ringle, \& Sarstedt, 2017), the values found for each ROS-21 scale reflected an appropriate accuracy of these measures. 


\section{Discussion}

The present study aimed to analyze the structural validity and internal consistency of the Religious Orientation Scales (Batson \& Ventis, 1982) among Spanish Catholic people. A CFA showed a poor fit of the 31-item ROS model (Ramírez, 2006). Thus, a PCA with Equamax rotation method was carried out. The process resulted in a 21-item three correlated components model (ROS-21) with a good fit and internal consistency between acceptable and excellent.

\section{Structural validity of the ROS-21}

Regarding the results obtained in the present study, there are some differences with the Batson and Ventis (1982) model: item 15, which was included by Batson and Ventis (1982) in the intrinsic scale, was discarded in the present study; items 3, 29, 16, and 17, which were included by Batson and Ventis (1982) in the quest scale, were discarded in the present study; items 1, 4, 10, 13, and 18, which were included by Batson and Ventis (1982) in the extrinsic scale, were discarded in the present study; item 8, which was included by Batson and Ventis (1982) in the quest scale, was included in the intrinsic scale in the present study, probably because that item refers to meaning in life, which is significantly related to intrinsic religiosity (e.g., García-Alandete et al., 2013). In summary, concerning the Batson and Ventis (1982) model, all the three scales were reduced (especially both the quest and extrinsic ones), and the intrinsic scale included the item 8 , in which religiosity is related to meaning in life.

Both the extrinsic and quest scales obtained in the present study were one-dimensional, rather than two-dimensional and three-dimensional, respectively, in contrast to other studies (e.g., Altemeyer \& Hunsberger, 1992; Beck \& Jessup, 2004; Brewczynski \& MacDonald, 2006; Donahue, 1985; Gorsuch \& McPherson, 1989; Gorsuch \& Venable, 1983; Kirkpatrick, 1989; Leak, 2011; Neyrinck et al., 2010).
Internal consistency of the ROS-21

Regarding the internal consistency of the 21item for the ROS obtained in the present study, the Cronbach's alpha was higher for the intrinsic scale but lower for the extrinsic scale than in Allport and Ross (1967). Likewise, the Cronbach's alpha was higher for both the intrinsic and quest scales than it was in Batson and Ventis (1982), and equal for the extrinsic scale. These data agree with previous studies (e.g., Batson \& Schoenrade, 1991b; Darvyri et al., 2014; García-Alandete \& Bernabé, 2013). Also, the $\mathrm{CR}$ values showed an appropriate accuracy of all the three religious orientation scales of the ROS- 21.

In summary, as noted above, the 21-item model for the ROS is a scale with good structural validity and internal consistency.

Limitations of the present study and suggestions for future research

Some limitations of this study should be pointed out. First, the sample was only composed of undergraduates, most of them young people. Future studies should consider more representative samples of the general population. Second, the sample was composed exclusively of Catholic people; it would be important to use more heterogeneous samples, in terms of belonging to different religious identities (Muslims, Buddhists, Christians, others) (e.g., Johnstone et al., 2012), and a crosscultural perspective (e.g., Ghorbani, Watson, Gharamaleki, Morris, \& Hood, 2002). Likewise, to use a larger sample would allow to carry out multi-group confirmatory factor analysis (e.g., men and women, age subsamples).

It is necessary to further examine the construct validity and reliability of the ROS (e.g., Beck, Baker, Robbins, \& Dow, 2001; Beck \& Jessup, 2004; Donahue, 1985), in order to consider the idiosyncrasies of different religions and sociocultural contexts in the assessment of religious orientations (e.g., Flere et al., 2008; Flere \& Lavrič, 2008). It is also important to 
analyze the relationships between the religious orientations and other variables, such as the empathy and social desirability (Watson, Hood, Morris, \& Hall, 1984), type of religious internalization (Ryan, Rigby, \& King, 1993) or religious denomination (Maltby \& Lewis, 1996), the field dependence/independence cognitive style (Barrett, Patock-Peckham, Hutchinson, \& Nagoshi, 2005), rigidity (Maltby, 1998) and other personality variables (Maltby, 1999b) emotional intelligence (Liu, 2010) and self-determination (Neyrinck et al., 2010) among others, as well as the differences between the various religions (which might condition the meaning and comprehension of the items). More conservative and authoritarian religions, such as Islam, especially its more radical forms, might negatively influence the QRO and positively influence both the IRO and the ERO. By contrast, religions that recognize freedom of conscience and a more personalized religiosity, such as Lutheranism or Buddhism, might positively influence the QRO. In addition, the process of secularization and other cultural characteristics might also positively influence the $\mathrm{QRO}$ (in addition to atheism and religious indifference, of course; Cfr. Watson, Morris, \& Hood, 1992), among others (Cfr. Kristensen, Pedersen, \& Williams, 2002; Miner, 2008).

Finally, it seems to be particularly important to analyze whether the Quest orientation is a mature form of religiosity (Batson \& Ventis, 1982), an expression of agnosticism (Beck \& Jessup, 2004; Donahue, 1985), or a transitional form of religiosity related to doubt and the search for one's personal identity in early adulthood (e.g. Donahue, 1985; Klaassen \& McDonald, 2002; Kojetin, McIntosh, Bridges, \& Spilka, 1987; Spilka, Kojetin, \& McIntosh, 1985). It might also be important to clarify its relationships with Intrinsic and Extrinsic religious orientations.

\section{Conclusions}

The present study analyzed the structure of Batson and Ventis (1982) Religious Orientation Scale (ROS) in a sample of Spanish Catholic people, obtaining a 21-item three-component (intrinsic, extrinsic, and quest scales) using both exploratory and confirmatory procedures. That model showed a reasonable adjustment, and the three scales showed an internal consistency between acceptable and good. However, further studies are necessary to clarify the nature of the religious orientations and their relationship, also to consider the idiosyncrasies of different religions and sociocultural contexts in the assessment of religious orientations.

\section{References}

Allen, R. O., \& Spilka, B. (1967). Committed and Consensual Religion: A Specification of Religion-Prejudice Relationships. Journal for the Scientific Study of Religion, 6(2), 191-206. https://doi.org/10.2307/1384046

Allport, G. W. (1950). The individual and his religion. New York, NY: MacMillan.

Allport, G. W., \& Ross, J. M. (1967). Personal religious orientation and prejudice. Journal of Personality and Social Psychology, 5(4), 432-443. https://doi.org/10.1037/h0021212

Altemeyer, B., \& Hunsberger, B. (1992). Authoritarianism, Religious Fundamentalism, Quest, and Prejudice. The International Journal for the Psychology of Religion, 2(2), 113-133. https://doi.org/10.1 207/s15327582ijpr0202_5

Barrett, D. W., Patock-Peckham, J. A., Hutchinson, G. T., \& Nagoshi, C. T. (2005). Cognitive motivation and religious orientation. Personality and Individual Differences, 38(2), 461-474. https://doi.org/ 10.1016/j.paid.2004.05.004

Batson, C. D. (1976). Religion as prosocial: Agent or double agent? Journal for the Scientific Study of Religion, 15(1), 29-45. htt ps://doi.org/10.2307/1384312

Batson, C. D., \& Schoenrade, P. A. (1991a). Measuring Religion as Quest: 1) Validity Concerns. Journal for the Scientific Study of Religion, 30(4), 416-429. https://doi.org/10. 2307/1387277 
Batson, C. D., \& Schoenrade, P. A. (1991b). Measuring Religion as Quest: 2) Reliability Concerns. Journal for the Scientific Study of Religion, 30(4), 430-447. https://doi.org/10. 2307/1387278

Batson, C. D., \& Ventis, W. L. (1982). The religious experience: A social-psychological perspective. New York, NY: Oxford University Press.

Batson, C. D., \& Ventis, W. L. (1985). Misconception of quest: A reply to Hood and Morris. Review of Religious Research, 26(4), 398-407. https://doi.org/10.2307/35 11053

Batson, C. D., Schoenrade, P. A., \& Ventis, W. L. (1993). Religion and the individual: A social-psychological perspective. New York, NY: Oxford University Press.

Beck, R., Baker, L., Robbins, M., \& Dow, S. (2001). A second look at Quest motivation: Is Quest unidimensional or multidimensional? Journal of Psychology and Theology, 29(2), 148-157. https://doi.org/10 $.1177 / 009164710102900206$

Beck, R., \& Jessup, R. K. (2004). The Multidimensional Nature of Quest Motivation. Journal of Psychology and Theology, 32 (4), 283-294. https://doi.org/10 $.1037 / \mathrm{t} 22533-000$

Bentler, P. M. (2006). EQS (Version 6.1) [Computer software]. Encino, CA: Multivariate Software.

Brewczynski, J., \& MacDonald, D. A. (2006). Confirmatory Factor Analysis of the Allport and Ross Religious Orientation Scale with a Polish Sample. The International Journal for the Psychology of Religion, 16(1), 63-76. http s://doi.org/10.1207/s15327582ijpr1601_6

Brown, T. A. (2015). Confirmatory factor analysis for applied research. New York, NY: Guilford Press.

Brown, S. R., \& Westman, A. (2011). Refining Christian Religious Orientations through Cluster Analyses. Archive for the Psychology of Religion, 33 (2), 229-239. https://doi.org/1 0.1163/157361211X570056

Browne, M. W., \& Cudeck, R. (1993). Alternative ways of assessing model fit. In
K. A. Bollen \& J. S. Long (Eds.), Testing Structural Equation Models (pp. 136-162). Newbury Parck, CA: Sage.

Cohen, J. (1988). Statistical Power Analysis for the Behavioral Sciences (2nd ed.). New York, NY: Erlbaum.

Darvyri, P., Galanakis, M., Avgoustidis, A. G., Pateraki1, N., Vasdekis, S., \& Darviri, C. (2014). The Revised Intrinsic/Extrinsic Religious Orientation Scale in a Sample of Attica's Inhabitants. Psychology, 5(13), 1557-1567. https://doi.org/10.4236/psych.2 014.513166

Donahue, M. J. (1985). Intrinsic and extrinsic religiousness: review and meta-analysis. Journal of Personality and Social Psychology, 48(2), 400-419. https://doi.org/10.1037/00 22-3514.48.2.400

Feagin, J. R. (1964). Prejudice and Religious Types: A Focused Study of Southern Fundamentalists. Journal for the Scientific Study of Religion, 4(1), 3-13. https://doi.org $/ 10.2307 / 1385200$

Flere, S., \& Lavrič, M. (2008). Is intrinsic religious orientation a culturally specific American Protestant concept? The fusion of intrinsic and extrinsic religious orientation among nonProtestants. European Journal of Social Psychology, 38(3), 521-530. https://doi.org/ 10.1002/ejsp.437

Flere, S., Edwards, K. J., \& Klanjsek, R. (2008). Religious Orientation in Three Central European environments: Quest, Intrinsic, and Extrinsic Dimensions. The International Journal for the Psychology of Religion, 18(1), 1-21. https://doi.org/10.1080/10508610701 719280

Francis, L. J. (2007). Introducing the New Indices of Religious Orientation (NIRO): Conceptualization and measurement. Mental Health, Religion and Culture, 10(6), 585-602. https://doi.org/10.1080/13674670 601035510

García-Alandete, J., \& Bernabé, G. (2013). Religious orientation and psychological well-being among Spanish undergraduates. 
Acción Psicológica, 10(1), 133-148. https://d oi.org/10.5944/ap.10.1.7040

García-Alandete, J., Rosa, E., Sellés, P., \& Soucase, B. (2013). Orientación religiosa y sentido de la vida [Religious Orientation and Meaning in Life]. Universitas Psychologica, 12 (2), 363-374. https://doi.org /10.11144/Javeriana.UPSY12-2.orsv

Ghorbani, N., Watson, P. J., Gharamaleki, A. F., Morris, R. J., \& Hood, R. W. (2002). Muslim-Christian Religious Orientations Scale: Distinction, correlations, and crosscultural analysis in Iran and the United States. The International Journal for the Psychology of Religion, 12(2), 69-91. https:// doi.org/10.1207/S15327582IJPR1202_01

Gorsuch, R. L., \& McPherson, S. E. (1989). Intrinsic/extrinsic measurement: I/ E revised and single-item scales. Journal for the Scientific Study of Religion, 28(3), 348-354. https://doi.org/10.2307/1386745

Gorsuch, R. L., \& Venable, G. D. (1983). Development of an "Age Universal" I-E Scale. Journal for the Scientific Study of Religion, 22(2), 181-187. https://doi.org/10. 2307/1385677

Hair, J. F., Hult, G. M., Ringle, C. M., \& Sarstedt, M. (2017). A primer on partial least squares structural equation modeling (PLSSEM) (2nd ed.). Thousand Oaks, CA: Sage Publications.

Hair, J. F., Anderson, R. E., Tatham, R. L., \& Black, W. C. (2006). Multivariate Data Analysis (6th ed.). Upper Saddle River, NJ: Pearson Prentice Hall.

Hunt, R. A., \& King, M. B. (1971). The intrinsicextrinsic concept: A review and evaluation. Journal for the Scientific Study of Religion, 10(4), 339-356. https://doi.org/10.2307/13 84780

IBM. (2013). IBM SPSS Statistics for Windows, Version 22.0. Armonk, NY: IBM Corp.

Jaume, L., Simkin, H., \& Etchezahar, E. (2013). Religious as quest and its relationship with intrinsic and extrinsic orientation. International Journal of Psychological Research, 6(2), 71-78.
Retrieved from http://www.scielo.org.co/pd f/ijpr/v6n2/v6n2a08.pdf

Johnstone, B., Yoon, D. P., Cohen, D., Schopp, L. H., McCormack, G., Campbell, J., \& Smith, M. (2012). Relationships among Spirituality, Religious Practices, Personality Factors, and Health for Five Different Faith Traditions. Journal of Religion and Health, 51(4), 1017-1041. https://doi.org/10.1007/s 10943-012-9615-8.

Khodadady, E., \& Bagheri, N. (2012). Construct Validation of a Modified Religious Orientation Scale within an Islamic Context. International Journal of Business and Social Science, 3(11), 237-246. Retrieved from http://www.ijbssnet.com/jo urnals/Vol_3_No_11_June_2012/26.pdf

Khodadady, E., \& Golparvar, E. (2011). Factors underlying religious orientation scale: A methodological approach. Ilahiyat Studies: A Journal on Islamic and Religious Studies, 2(2), 215-235. https://doi.org/10.12730/13 091719.2011 .22 .38

Kirkpatrick, L. A. (1989). A Psychometrick Analysis of the Allport-Ross and Feagin Measures of Intrinsic-Extrinsic Religious Orientation. In D. O. Moberg \& M. L. Lynn (Eds.), Research in the Social Scientific Study of Religion, Vol. 1 (pp. 1-30). Greenwich, UK: JAI Press.

Kirkpatrick, L. A., \& Hood, R. W. (1990). Intrinsic-Extrinsic religious orientation: The boon or bane of contemporary psychology of religion? Journal for the Scientific Study of Religion, 29(4), 442-462. h ttps://doi.org/10.2307/1387311

Klaassen, D. W., \& McDonald, M. J. (2002). Quest and identity development: Reexamining pathways for existential search. The International Journal for the Psychology of Religion, 12(3), 189-200. https://doi.org/10. 1207/S15327582IJPR1203_05

Kojetin, B. A., McIntosh, D. N., Bridges, R. A., \& Spilka, B. (1987). Quest: Constructive Search or Religious Conflict? Journal for the Scientific Study of Religion, 26(1), 111https://doi.org/115. doi:10.2307/1385845 
Kristensen, K. B., Pedersen, D. M., \& Williams, R. N. (2002). Profiling religious maturity: The relationship of religious attitude components to religious orientations. Journal for the Scientific Study of Religion, 40(1), 75-86. https://doi.org/10.1111/00218294.00039

Leak, G. K. (2011). Confirmatory factor analysis of the Quest Religious Orientation Scale. Social Behavior and Personality, 39(9), 1289-1290. https://doi.org/10.2224/sbp.20 11.39.9.1289

Liu, C.-C. (2010). The Relationship between Personal Religious Orientation and Emotional intelligence. Social Behavior and Personality, 38(4), 461-468. https://doi.org/ 10.2224/sbp.2010.38.4.461

Maltby, J. (1998). Religious Orientation and Rigidity. The Journal of Psychology, 132(6), 674-676. https://doi.org/10.1080/00223989 809599299

Maltby, J. (1999a). The internal structure of a derived, revised, and amended measure of the Religious Orientation Scale: the 'AgeUniversal' I-E Scale-12. Social Behaviour and Personality, 27(4), 407-412. https://doi. org/10.2224/sbp.1999.27.4.407

Maltby, J. (1999b). Personality Dimensions of Religious Orientation. The Journal of Psychology, 133(6), 631-640. https://doi.org /10.1080/00223989909599769

Maltby, J. (2002). The Age Universal I-E Scale-12 and orientation toward religion: Confirmatory factor analysis. The Journal of Psychology, 136(5), 555-560. https://doi.org /10.1080/00223980209605550

Maltby, J., \& Day, L. (1998). Amending a measure of the Quest religious orientation: applicability of the scale's use among religious and non-religious persons. Personality and Individual Differences, 25(3), 517-522. https://doi.org/10.1016/SO 191-8869(98)00078-6

Maltby, J., \& Lewis, C. A. (1996). Measuring intrinsic and extrinsic orientation toward religion: Amendments for its use among religious and non-religious samples. Personality and Individual Differences, 21 (6),
937-946. https://doi.org/10.1016/S0191-88 69(96)00154-7

Maltby, J., Lewis, C. A., Freeman, A., Day, L., Cruise, S. M., \& Breslin, M. J. (2010). Religion and health: The application of a cognitive-behavioural framework. Mental Health, Religion and Culture, 13(7-8), 749-759. https://doi.org/10.1080/13674670 802596930

Miner, M. H. (2008). Healthy questing and mature religious reflection: Critique, antecedents, and relevance of attachment theory? Journal of Psychology and Theology, 36(3), 222-233. https://doi.org/10.1177/00 9164710803600305

Neyrinck, B., Lens, W., Vansteenkiste, M., \& Soenens, B. (2010). Updating Allport's and Batson's Framework of Religious Orientations: A Reevaluation from the Perspective of Self-Determination Theory and Wulff's Social Cognitive Model. Journal for the Scientific Study of Religion, 49(3), 425-438. https://doi.org/10.1111/j.1468-59 06.2010.01520.x

Núñez-Alarcón, M., Moreno-Jiménez, M. P., Moral-Toranzo, F., \& Sánchez, M. (2011). Validation of a religious orientation scale in Christian and Muslim samples. Metodología de Encuestas, 13, 97-119. Retrieved from http://casus.usal.es/pkp/index.php/M $\mathrm{dE} /$ issue/view/144

Ramírez, M. C. (2006). Una adaptación española de la Escala de Orientación Religiosa de Batson y Ventis [A Spanish adaptation of the Batson and Ventis' Religious Orientation Scale]. Revista de Psicología General y Aplicada, 59(1-2), 309-318. Retrieved from https://www.researchgate.net/publica tion/313377133_Una_adaptacion_espanol a_de_la_Escala_de_Orientacion_Religiosa _éde_Batson_y_Ventis

Ryan, R. M., Rigby, S., \& King, K. (1993). Two types of religious internalization and their relations to religious orientations and mental health. Journal of Personality and Social Psychology, 65(3), 586-596. https://d oi.org/10.1037/0022-3514.65.3.586 
Satorra, A., \& Bentler, P. M. (2001). A scaled difference chi-square test statistic for moment structure analysis. Psychometrika, 66(4), 507-514. https://doi.org/10.1007/BF 02296192

Simkin, H., \& Etchezahar, E. (2013). The Extrinsic and Intrinsic Religious Orientations: Validation of the "Age Universal" I-E Scale in the Argentinian Context. Psykhe, 22 (1), 97-106. https://doi. org/10.7764/psykhe.22.1.477

Spilka, B., Kojetin, B. A., \& McIntosh, D. N. (1985). Forms and Measures of Personal Faith: Questions, Correlates, and Distinctions. Journal for the Scientific Study of Religion, 24(4), 437-442. https://doi.org/1 $0.2307 / 1385997$

Voci, A., Bosetti, G., \& Veneziani, C. A. (2017). Measuring religion as end, means, and quest: The Religious Life and Orientation Scale. Testing, Psychometrics, Methodology in Applied Psychology, 24, 83-98, https://doi.or g/10.4473/TPM24.1.5

Watson, P. J., Morris, R. J., \& Hood, R. W. (1989). Interactional factor correlations with Means and End religiousness. Journal for the Scientific Study of Religion, 28(3), 337-347. https://doi.org/10.2307/1386744

Watson, P. J., Hood, R.W., Morris, R. J., \& Hall, J. R. (1984). Empathy, Religious Orientation, and Social Desirability. The Journal of Psychology, 117(2), 211-216. https://doi.org /10.1080/00223980.1984.9923679

Watson, P. J., Morris, R. J., \& Hood, R. W. (1992). Quest and identity within a religious ideological surround. Journal of Psychology and Theology, 20 (4), 376-388. htt ps://doi.org/10.1177/009164719202000405

\section{Notes}

* Research article. 